\title{
Assessment of Multifunctional Urban Land Use Benefits an Actor-Oriented Framework
}

\author{
Caroline A. Rodenburg* and Peter Nijkamp**
}

\begin{abstract}
This paper seeks to position the increasingly popular concept of multifunctional land use in the context of urban planning and urban land rent theory. It aims to design a framework for identifying the benefits of multifunctionality in land use by offering a typological approach to three classes of actors (stakeholders and beneficiaries) involved, viz. investors, organizations and users.
\end{abstract}

JEL Classification : R14, R52

Keywords: Urban Quality, Multifunction Land Use, Land Market Failure

\section{Setting the Scene}

Urban quality is an important focal point in the modern planning discipline. It addresses the traditional concern on the physical environment in the city (such as pollution or noise) but it refers increasingly to the conditions that make a modern city livable and vital, including the spatial layout. We will in this paper start from an environmental angle, but position urban quality in the modern context of multifunctional land use.

Environmental concerns have been with us for several decades already. Since Rachel Carson's 'Silent Spring' [14] an avalanche of public statements, scientific studies and policy proposals has been published. Ecological decay has been one of the most severe issues in the second part of the $20^{\text {th }}$ century and will continue to be so in this century. In a way, one might argue that the disturbance of the earth' ecosystem is one of the most risky experiments mankind has ever undertaken, in particular as there is no guarantee that the experiment will be successfully concluded.

Admittedly, the environmental case is not a hopeless one. The awareness of environmental decay has grown drastically and our scientific insights into the causes of and remedies against ecological disturbance have led to many new findings. As a consequence, human behaviour has turned into more environmentally-benign ways of living ; industrial activities have become far less polluting, more resource-saving and more energy-efficient, while environmental policy has become an established part of public policy.

In the past decades, sustainable development has become a fashionable concept, from both an analytical and a policy perspective. The fuzziness of the concept has also prompted

* Ernst \& Young, Real Estate Advisory Services and International Location Advisory Services, Euclideslaan 1, 3584 BL Utrecht, The Netherlands

E-mail : caroline.rodenburg@nl.ey.com

** Department of Spatial Economics, Free University Amsterdam, De Boelelaan 1105, 1081 HV Amsterdam, The Netherlands

E-mail : pnijkamp@feweb.vu.nl 
the need for more tangible interpretations in a more concrete setting, such as sustainable tourism, sustainable mobility, sustainable agriculture or sustainable urbanization. Against this background, the notion of urban sustainability has gained much popularity. The idea of sustainable modes of urban living and working is undoubtedly an important issue for scientific research and policy initiatives, as an increasing share of the world population is living in cities.

For a long time, cities have been regarded as sources of environmental evil, but more recently we are witnessing a re-appreciation of cities as places which through their agglomeration advantages are able to offer a place for working and living that is ecologically more efficient than any other settlement pattern. The decisive factor in urban ecological quality is land use management.

Different forces, such as spatial variation in population densities, the economic structure of a region, and differences in consumer demand across space according to regional variation in consumer tastes, influence the local demand for specific land use functions. In particular, the relatively high population density in the Netherlands, compared with other European countries, causes a relatively high demand for space: space to live, to work, to recreate, etc. Together with current land use policies aimed at the protection of open space, the high population density exerts a high pressure on the urban land market, resulting in high land prices in urban environments. These high prices are leading to a growing interest in the efficient and intensive use of urban space.

The high urban land rents, together with the increasing pressure on the infrastructure network due to the spatial separation of different land use functions and a desire to create a local competitive advantage via an increase in spatial quality, have led to the investigation of possibilities to combine different land use functions within demarcated areas. City planners introduced the term 'multifunctional land use' as a spatial planning concept aimed at the combination of different land use functions in order to save scarce space. Economists, on the other hand, would not consider multifunctional land use as a goal, but rather as an efficiency instrument to decrease the relative shortage of space and to improve spatial quality.

Traditionally, economists have focussed on 'monofunctional land use' : the spatial segregation of functions. An example is the standard concentric land use theory of Von Thünen, which forms (via Alonso, Muth and many others) the basis for the 'bid-rent approach'. This model predicts concentric spatial functional specialisation around a city's Central Business District (CBD), driven by free-market price formation.

Shortcomings of the paradigm of monofunctional land use were first voiced by Jane Jacobs in her book 'The Death and Life of Great American Cities' [34]. In this book, she claims that dense mixed urban quarters are more economically viable, more socially stable, more culturally and aesthetically interesting, and safer than monofunctional dormitory suburbs. Recently the idea of 'multifunctional land use' has re-emerged, but for different - or rather additional reasons-such as the hoped-for saving in land use and the belief that it generates less traffic than monofunctional land use patterns (see, e.g., Banister [5]; Coupland [18]; Harts et al. [30]). Through a multifunctional design of the spatial organisation, benefits could be obtained by practising several (complementary or mutually 
strengthening) functions at the same location.

The aim of the present paper is to map out the economic benefits of multifunctional urban design. The focus in the paper will be on multifunctional land use projects, interpreted as demarcated urban areas in which a multifunctional development will take place. We thus seek to assess the benefits from multifunctional land use projects for different actors who have an interest in the development of a multifunctionally-designed urban area. We will do so by using an actor-oriented approach.

\section{Multifunctional Land Use : An Economic Perspective}

Economic science has traditionally had great interest in land use. Economists have typically focussed on questions of the efficiency and (more recently) the sustainability of land use. Such studies were often implicitly or explicitly concerned with functional segregation of land use functions (see, e.g., Von Thünen [65] ; Alonso [1]). Nowadays, however, increasing attention is being paid to multifunctionality of urban space (see, e.g., Coupland [18]; Congress for the New Urbanism [17]).

An interesting question in this respect concerns the role of the land market. Land is a scarce commodity, which has a market value depending on its use (e.g., work and business, residential housing, or agriculture). Different land use functions often compete with each other. The more functions are to be fulfilled in the same area (keeping the scale of operations constant), the scarcer the land concerned becomes. Particularly in densely populated areas, we witness competing demands that give an upward pressure on land prices. For social and economic reasons, this calls for a more intensive use of the available land, not only by differentiation of functions over time (e.g., sequentially over the day), but especially by seeking a vertical combination of the functions (i.e., construction in multi-layer constellations).

Traditionally, different types of land use functions have been studied as alternative and mutually exclusive uses of scarce land. From the 1960s onwards, however, it has been increasingly recognised that different types of land use functions are not necessarily conflicting, but that a simultaneous fulfilment of different functions within a demarcated area may create synergy (Jacobs [34]) as a special type of agglomeration externalities. Multifunctional land use refers to such a spatial concentration, combination and integration of different forms of land use on the same location.

The objective of multifunctional land use as a planning concept is to use scarce space as prudently as possible. As can be seen in the international planning literature, this objective is in accordance with other mixed land use concepts, such as 'new urbanism', 'smart growth', and the 'compact city' concept (see also Vreeker et al. [68]). The North American movement of new urbanism views design and planning as essential components for the high-quality development of neighbourhoods, which are based on short walking distances and contain a vibrant mix of housing and work environments (Congress for the New Urbanism [17]). There are two streams within new urbanism, which have different visions of mixed use (Grant [27]). Traditional neighbourhood design (TND) involves intensification and smallscale mixing of compatible uses, such as promoting apartments over garages, and residential units over stores in a diverse but low-rise town centre. This design supports urban infill and 
redevelopment approaches. Transit-oriented development (TOD), on the other hand, concentrates development in nodes associated with transit stations, thus creating an urban region structure with clusters of uses aligned in a density gradient from transit stations. This approach works best with greenfield development on new suburban sites. The smart growth movement, which emerged in the 1990s, proposes urban infill development, mixing land use functions, and the creation of transit and pedestrian-friendly environments as an answer to the spatial separation of land use functions (American Planning Association [2]). The explicit goal of smart growth is to protect open spaces and farmland (Vreeker et al. [68]). The compact city concept, on the other hand, is mainly aimed at reducing the growth of car mobility and is very common in European planning (Maat [47]). The rationale behind the compact city concept is straightforward: by increasing urban density and reducing travel distances between different activities, the need to travel is reduced and critical mass is created for the efficient provision of public transport and other amenities (Maat [47]).

These planning concepts all investigate various possibilities to reduce urban sprawl and to promote spatial and environmental quality (Hall [29]), emphasising the use of compact and mixed land use concepts (see, e.g., Coupland [18]). Various authors point out the importance of these concepts in the light of (urban) sustainability (Walker [69]; Capello and Nijkamp [12]). An important difference, nevertheless, between multifunctional land use and other mixed land use concepts is the clear focus in multifunctional land use on the exploitation of economies of synergy (Rodenburg et al. [59]) : more emphasis is placed on the relationship between mixed and compact land use, infrastructure and city redevelopment and revitalisation. The synergetic effects that may arise as a result of multifunctional land use are an important factor in the clustering of activities, assuming that spatial and functional clustering results in advantages of scale, such as cost reductions or better access to information and markets.

Besides the importance attributed to the synergy effects, in addition, demographic factors-together with current tendencies in society (such as commuting distances, environmental awareness, a desire to protect open space, and ICT developments) - have generated a great deal of interest in this (re)new(ed) form of urban architecture (see also Priemus et al. [55]). In densely populated countries like the Netherlands, multifunctional land use could save scarce space not only by differentiation of functions over time (e.g. sequentially), but especially also by seeking a vertical combination of the functions (i.e. construction in various layers).

We will now address the question whether multifunctional urban land use will spontaneously emerge or whether it needs dedicated government attention and intervention.

\section{Land Markets, Market Failures and Government Failures : An Overview}

\subsection{Land market theory}

The land market is a special type of market, which is usually subject to strong government involvement. Land has some properties that make it different from other goods (CPB [15]). First, the amount of land is fixed, apart from land that can be reclaimed from the sea. Second, the location of every parcel of land is fixed and is a unique property. Additionally, a parcel of land has a certain quality (fertility, stability, or other) that is usually difficult to 
change. And, finally, the use of a parcel of land often also affects the use and value of the surrounding parcels.

Starting an analysis of the land market from the above-mentioned specific characteristics of land, it is interesting to see how the price of land is determined. David Ricardo [56] is the originator of the idea that the price of agricultural land is determined by its fertility. The more productive the land, the more a farmer is willing to pay to use it (the 'land rent'). Farmers are price takers and maximise profit where price equals marginal cost. However, if there is competition among prospective farmers, prices of land are bid up to the point at which economic profit is zero. At any rent less than the maximum profit, the landowner will be able to find another farmer willing to pay slightly more to use the land. The equilibrium land rents make farmers indifferent between different parcels of land in use, since economic profits at any location where production takes place equal zero. The equalisation of equilibrium land rents to the excess of total revenue over non-land costs has been called the 'leftover principle' : the landowner gets the 'leftovers', or the pre-rent profits, because of competition for land among farmers (O'Sullivan [50]). This principle only holds in a free land market in which restrictions on entry and competition are absent.

The functioning of the (urban) land market can be analysed from a micro- and welfareeconomic perspective (for introductions into micro- and welfare economics, respectively, see Varian [66], and Johansson [37]). The efficiency of free market mechanisms is then an important starting point. In a free market where market failures are absent, the allocation of land over the different functions will take place efficiently and will result in a Pareto optimum. This means that there is no other allocation possible in which at least one of the parties can improve its position without making others worse off. According to the first welfare theorem, on such markets, individual behaviour focussed on maximising its own welfare leads to a market equilibrium in which the social Pigouvian welfare (i.e., the sum of individual levels of welfare of individual actors expressed in monetary terms) is maximised (Varian [66]). This is also called a Pareto optimum.

However, such a situation of 'perfect markets' should not be regarded as a realistic representation of most economic market processes in general, nor of land markets in particular. In practice, there are often external effects related to land use (see also Section 3.3), such as nuisance (e.g. noise) from other land use functions or environmental effects. Another necessary precondition for a socially-efficient allocation on a market is that buyers and sellers of land cannot individually influence the prices on the market. They should be price takers, and there has to be a competitive market. This condition is not always fulfilled in practice in land markets, as a result of, among other things, the unique character of land (in a particular location). As a consequence, buyers and sellers (within limits) can exercise market power and influence the price of land.

Therefore, a situation of 'perfect markets' should be regarded as a hypothetical benchmark, offering the opportunity to compare existing market forms. If the market process is analysed from the perspective of market failures, insights may be obtained into the most important barriers for realising investments in multifunctional land use, and it can be investigated whether it is advisable for the government to intervene in the market process, and what would be the most efficient way to do so. But before we do this, a description of 
land use in the spatial market will be given.

\subsection{The spatial market : organization of land use}

Theories on urban land use deal with the determinants of urban growth and spatial structure, and with the interactions between those determinants and their impact on spatial configurations. The urban land use market is subject to many forces, of which the most important drivers are the geographic, economic, demographic, political and social forces. These forces, as well as their mutual interactions, are continuously evolving, thereby making spatial structure a dynamic phenomenon that changes over time and space (Dowall [22]). Clearly, these different forces often cannot be seen in isolation, but will affect each other in various, complex ways. In this study, the focus will mainly be on the economic aspects of spatial organisation. Geographical, demographic, political and social aspects will sometimes be touched upon, but, in the main, the spatial organisation will be viewed from an economic point of view.

Current and future spatial development is often dependent on past development and on the current function of an area. The location of human activity usually has a long history that is reflected in rigid urban structures. This path dependency means that the actual spatial organisation is a logical starting point for analysing the future or potential land use of certain areas. The process of spatial organisation can be regarded as the functioning of a spatial economic market. Land markets develop where institutions exist to create and protect private property rights in land, where there are sufficient buyers and sellers of such rights, and where institutions exist to support formal contractual-based exchange (Webster and Lai [70]). This means that the major identifiable parts of the system are geographically differentiated demand and supply, as well as the interrelationships among these factors (Griffin et al. [28]). Figure 1 shows a simplified representation of the main (economic)

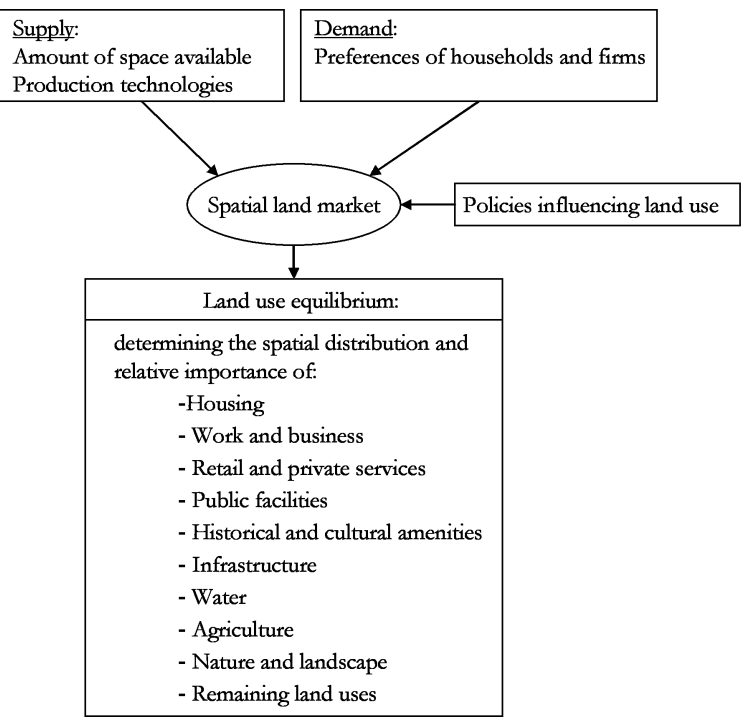

Figure 1: Forces influencing the spatial land market 
forces that influence the spatial organisation of the land market. The demand factors are represented by households and firms that have certain preferences concerning the consumption of goods or use of inputs, among which are space, nature and time. The supply factors affect the cost at which a certain quantity of a commodity can be offered within a given space and time. Together with policies influencing land use, these forces will result in a land use equilibrium in which the spatial distribution and relative importance of the different land use functions are determined.

An important determinant for the location of different land use functions is the costs involved with spatial interaction between different locations. These can be transport costs or communication costs, since spatial interaction - in a more general sense-involves the movement of people, goods, production factors or services, or the transfer of ideas and information. These costs evidently vary with the accessibility of the location concerned: each actor aims for an optimum spatial accessibility in order to save on transport and communication costs. Extensive research into the relation between transport and urban development has been carried out by, among others, Cervero [16] ; Rietveld [57] and [58] ; and Banister [4], [5], [6], [7]).

In a 'perfect' market, the confrontation of demand and supply will result in a spatial equilibrium in which the spatial distribution and relative importance of the various land use functions are determined in a socially-efficient way. However, since a situation of 'perfect markets' should not be regarded as a realistic situation in land markets, we will now describe forces that may hinder the realisation of a socially-efficient allocation of resources.

\subsection{Market failures related to the land market}

Next to demand and supply factors, the spatial land market is also influenced by governmental policies (see Figure 1). But why would governments want to be engaged in the land market? The main economic reason is that markets may fail in the efficient allocation of resources, and the marginal costs (or benefits) with which individuals are confronted in the production or consumption of certain goods and services differ from the social marginal costs (or benefits) (Johansson [37]). This leads to inefficiencies that are expressed by overor under-production and -consumption of these goods and services. These 'market failures' can appear in different forms. The most general forms of market failures are (Stiglitz [63]) :

- Failure of competition

- Public goods

- Externalities

- Incomplete markets

- Information failures

\section{Failure of competition}

For an efficient allocation of land through a free market it is necessary that buyers and sellers of land behave as if they cannot influence prices; there should be competitive markets. In the absence of strong competition in the land market, i.e. if there are so few suppliers or demanders active on the market that they can influence market prices, market 
power exists if only a few groups have land ownership and can decide to whom they sell land (this is often the government) or if someone owns a piece of land on a strategic location. The limited extent of substitution of parcels of land means that buyers and sellers can influence the prices of land, resulting in (potential) price differences within and between land use functions.

\section{Public goods}

Pure public goods are characterised by non-rivalry in consumption (consumption by one person does not affect the consumption possibilities of others) and non-excludability of consumption (it is impossible to exclude consumers from consumption). Public goods will in principle not be provided by the (free) market to a sufficient extent because of the free-rider problem. This means that it is not attractive for individuals to provide the facility themselves or to pay for it, but instead to take advantage of the extent to which others provide the facility. In order to reach a socially-optimal supply, it is logical to have it provided by representatives of the public interest: the government. In the land use market, the public goods issue mainly holds for infrastructure and public space. With these types of land use, the transaction costs of making people pay for the public good are so high that, in general, this does not happen. Public goods are very often part of multifunctional land use projects. The more land use functions are combined, or the higher the intensity of land use, the higher the need for transport infrastructure (to make and keep the land use functions accessible) and public space (to keep the area 'liveable' by means of urban green areas and playgrounds). This would call for a role for governments in the development process of multifunctional land use projects, to ensure the provision of these functions in a more efficient way than would be the result of a (free) market process.

\section{Externalities}

Externalities are unintended effects on the welfare of others that are not (fully) reflected in market prices. They can be subdivided into positive and negative effects: external benefits and costs, respectively. These effects may, for example, arise in urban areas when the value of a location varies strongly, depending on the character of the area and the use of adjacent land. For multifunctional land use projects, external effects may be one important reason why certain combinations of land use may be more favourable than others. Because of negative external effects, such as the exhaust and noise pollution of cars, houses can not be built too close to highways. In such a case, the social costs of transport are higher than the private costs as expressed on the market. Positive external effects of the combination of different land use functions, such as property and land value increases (Banister and Berechman [8]), often take the form of external economies of scale and scope. Economies of scale and scope can be experienced in different contexts. In our case, we will consider location-specific external economies of scale and scope, which are generally known as agglomeration economies and are important factors in the clustering of activities as in multifunctional land use projects. There are various types of agglomeration economies. One important distinction is between localisation and urbanisation economies (see e.g., Isard [33] ; Lambooy [45]; O’Sullivan [50]). 
Localisation economies occur when the production costs of firms in a particular industry decrease if the total local output of that industry increases. To realise such localisation economies, a firm must be located close to other firms in the industry. Localisation economies may occur for three main reasons (O'Sullivan [50]) :

(1) Scale economies in intermediate inputs: some geographic clusters of firms occur because firms in a particular industry buy an intermediate input from the same supplier, who operates under increasing returns to scale.

(2) Labour market economies: a cluster may increase the efficiency of the labour market for two reasons put forward by Alfred Marshall (Glaeser et al. [26]). First, employees have relatively low search costs, since information about jobs is available through informal channels and prospective employers are nearby, making formal job searches relatively easy. Second, because of the physical proximity of employers, moving costs are relatively low.

(3) Knowledge spillovers. Another idea of Marshall is that, in dense urban environments, there is a faster flow of ideas across workers (Jaffe et al. [35] ; Glaeser et al. [26]). A cluster facilitates the rapid exchange of information, knowledge and diffusion of technology.

Urbanisation economies occur if the production cost of an individual firm decreases as the total output of the urban area increases. They differ from localisation economies in two ways (O'Sullivan [50]). First, urbanisation economies result from the scale of the entire urban economy, and not simply the scale of a particular sector. Second, they involve benefits for firms from different sectors, and not just for firms in a particular industry.

The advantages from multifunctional land use thus arise as a result of the concentration of people and production. A final external effect that we would like to mention here is economies of density. Multifunctional land use creates density, enabling, for example, public transport to reach the critical mass necessary for incorporating the area in the public transport network, or for opera companies and art museums to reach a sufficiently large audience to be profitable (Glaeser et al. [26]; Rosenthal and Strange [60]).

\section{Incomplete markets}

Whenever private markets fail to provide a good or service, even though the cost of providing it is less than what individuals are willing to pay, there is a market failure that we refer to as 'incomplete markets' (Stiglitz [63]). For our study, the most relevant markets in which this failure occurs are complementary markets. In such markets, each actor acting alone would not be able to pursue the public interest, but acting together they could. This is particularly relevant for multifunctional land use projects, which require extensive coordination among different types of actors in the development process. In such cases, largescale (government) coordination is required and would justify public urban development programmes.

\section{Information failures}

The belief that the market, by itself, will supply too little information leading to imperfect information on the part of different actors, forms a motivation for government 
intervention (Stiglitz [63]). Especially in cases where information is distributed asymmetrically over different market players and the goals of these players do not coincide, information costs may have a large impact on investment decisions. When such frictions are present in the market environment, transactions in goods and services are costly due to behavioural and external factors such as bounded rationality, opportunism, uncertaintycomplexity, and small numbers exchange (Williamson [71]; Furubotn and Richter [25]). The relevance of this type of market failure for multifunctional land use seems great when the prospective benefits of the project depend on agglomeration externalities between a set of (key) users. In that case, the (key) users will have to invest in obtaining the necessary information in order to be able to capitalise on the agglomeration externalities and maximise profits.

\section{Summary}

The long-term behaviour of actors in the land use market can be assumed to be guided by profit maximising or utility maximising locational behaviour. This means that, theoretically, the activity that can most successfully exploit the locational attributes of a given site will in the long run probably gain it through competitive bidding (see Fujita [24]). The market economy, in which numerous individual public decisions are reflected, is not only capable of allocating land among competing uses, but would, given certain conditions, achieve maximum efficiency in doing so, both in terms of the use to which a site is put and in terms of the type of building erected. Since these 'certain conditions' are not always fulfilled, the free market may not achieve full efficiency in the allocation of resources (Harvey [31]). An economic motive for government intervention then arises. Therefore, it is appropriate to examine in the next section the role of planning control as an instrument to deal with defects in the market economy.

\subsection{Government intervention and failures related to the land market}

As discussed above, the existence of market failures in the land market may provide a valid reason for governments to intervene in the land market. Although the possibilities to reach the desired allocation may be limited, government regulation could be a solution for some kinds of market failures. However, government intervention may itself also lead to failures, for which various sources can be identified. Both government intervention and its failures will be discussed in the remainder of this section.

\section{Government intervention}

Many Western European countries have a land use planning system in the sense that a hierarchy of planning functions exists, ranging from municipalities to the central government (Cullingworth [20]). At all levels of government, there are different instruments available to change markets that are not functioning efficiently: they can take direct action, provide price incentives to the private sector, or enforce action in the private sector (Stiglitz and Driffill [64]). 


\section{Direct action}

When governments believe that the market fails in the provision of a good or service, they can nationalise the sector or part of the industry and provide the goods and services themselves or purchase the good from the private sector and provide it to citizens. In many cases, governments have an extensive role in the provision of infrastructure and urban green areas.

\section{Providing price incentives to the private sector}

Governments can also decide to operate at a distance, and use price incentives to change the outcome of private markets in desirable ways. They can provide such incentives through subsidies or taxes.

\section{Enforcing action in the private sector}

Concern about the effectiveness of incentives in achieving the desired result or about their cost may lead governments to use legal sanctions to get people to comply. An example is that property developers who want to get planning permission for a large housing project may be forced to provide a certain number of units for low-income individuals.

\section{Government failures}

Governments need to consider each of the above-mentioned alternatives for intervention and assess the chance that one of them will succeed. Such an assessment might lead to the conclusion that it is better not to intervene at all since various sources of government failures exist. The most important sources for such government failures are imperfect information and unforeseen responses (Stiglitz and Driffill [64]).

\section{Imperfect information}

Governments aim to minimise efficiency losses due to market failures and aim to maximise social welfare. However, in practice, the social welfare optimum is often not known. This could result in a sub-optimal allocation of land or a sub-optimal combination of different land use functions due to a lack of information, because of which the possible benefits of multifunctional land use projects might not be fully exploited by the different actors on the land market.

\section{Unforeseen responses}

The success or failure of programmes in the public sector depends not only on public officials but also on how the affected parties respond. Predicting those responses is difficult. For example, suppose that the government wants to decrease mobility by dictating a certain density of combined land use functions, and a statistical calculation proves the direct benefits of this policy. However, the desired urban density could provoke the reaction that the people concerned leave the area in their spare time to fulfil their need for space and serenity. In this case, the net effect of the measure could turn out to be negative. 


\section{Summary}

The previous examples of government failures hint at the possibility that government intervention in markets, including public sector production of public and/or private goods, does not necessarily move the economy closer to the attainment of a Pareto-efficient allocation (Johansson [37]). With regard to multifunctional land use, in many countries with a strict spatial planning system, based on zoning of activities, government intervention as well as its failures may lead to monofunctional areas and market distortions that prevent a certain optimal degree of multifunctionality to come into existence via the market mechanism. On the other hand, government intervention could also lead to development of multifunctional land use projects in order to uplift the image of a city, without evidence of sufficient support from market parties. These examples illustrate that government intervention in the land market does not necessarily lead to a socially-desirable degree of multifunctionality in urban development projects. A major factor of importance here is the multi-actor natures of multifunctional and use projects. This issue will be discussed in the next section.

\section{Actors in Multifunctional Land Use Projects}

In the previous sections, we have characterised multifunctional land use and analysed the functioning of the urban land market. In order to assess the feasibility of multifunctional urban land use, we now focus on demarcated multifunctional land use projects. The analysis of a clearly defined area will enable us to obtain knowledge about benefits of a multifunctionally-designed area more easily, compared with larger geographical scale levels. A project approach enables us to distinguish within a multifunctional development process different groups of actors, who all together are responsible for the ultimate success of the project.

Land use allocation problems can be identified as complex planning problems, with a large number of actors involved (Carsjens and van der Knaap [13]). The built environment is the result of interactions on the land market between agents and institutions within the local economy, on the one hand, and with regional and (inter)national financial and development interests, on the other (van der Krabben and Lambooy [41]). Among them are public as well as private actors, who may have different aims in the process of a multifunctional development (Shefer [61]).

The benefits of multifunctional land use projects accrue to the distinct types of actors in the project. To obtain insight into the size of the benefits that accrue to each type of actor and to see from where these benefits arise, we will first identify possible variables in the utility or profitability function of the identified types of actors.

The different land use functions as presented in Figure 1 help us to order the different groups of actors that may play a role in urban multifunctional land use projects. If we start from the different land use functions and see what types of stakeholders play a role in the development of the respective land use functions at a multifunctionally-designed site, a distinction between different layers of actors emerges. Figure 2 depicts these layers. The dotted vertical lines connecting one horizontal layer of actors with another represent stakeholders who act on more than one level and who thus have different roles at the same time, 


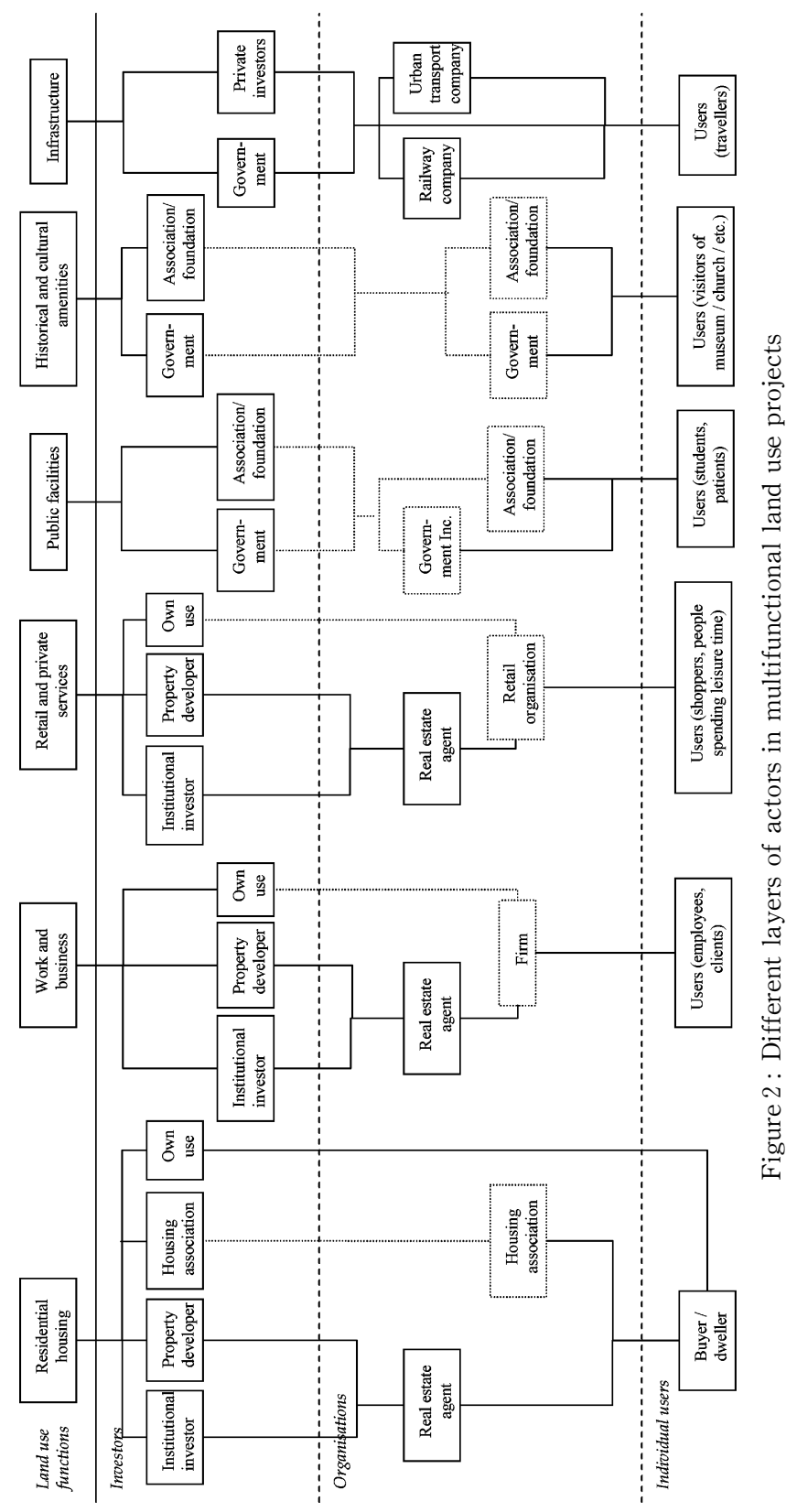


whereas the continuous vertical lines represent the relations between stakeholders at different levels. Of course, interactions also take place between stakeholders within one layer who are simultaneously involved in, or make use of different land use functions, but these are less relevant for our goal to identify different layers of actors.

We see that, for each land use function, the first (horizontal) layer of actors consists of the investors in multifunctional land use projects. Examples of investors are property developers, institutional investors, and commercial companies developing property for their own use. In the second layer, we find organisations (firms, retailers, etc.) that rent or own space at multifunctionally-designed sites. Examples of stakeholders in this group are companies that rent or own office or retail space, housing associations, institutions that manage the operationalisation of public and private facilities or amenities, but also transportation companies using the infrastructure at the site. The final, third, layer consists of individual users of the site. Individual users are those people who make use of the different land use functions and the related activities offered after realisation of the multifunctionallydesigned project. The most important groups of individual users of the site that can be distinguished are employees of a company located at the site, residents living at the site, people who visit the site for leisure purposes (e.g. shopping), and travellers who change means of transport at the site. We may thus distinguish three classes of actors-beneficiaries.

Understanding the behaviour of different types of actors in a multifunctional land use project is vital to the assessment of the resulting benefits. Choosing whether or not to do something is a ubiquitous state of activity for each type of actor (Louviere et al. [46]). The neo-classical economic approach of the behaviour of actors focusses on cost-minimising or profit-maximising theories. The emphasis in such theories is on the assumption of full information and rational behaviour, which means that the ultimate choice of actors between different alternatives implies that the alternative chosen maximises profit or utility. Under these assumptions, the general goals of each of the three types of actors as identified in Figure 2 can roughly be classified as follows: investors investing in, and organisations located at, multifunctionally-designed sites aim for profit maximisation ; and individuals aim for utility maximisation. These three classes of actors are the ones benefiting from land use developments.

Although the neo-classical approach is useful as a benchmark that defines the 'optimal' behaviour of actors in economic terms, it does not take into account the behaviour of actors in a context with imperfect information and uncertainty (Pellenbarg et al. [52]). This has led to the development of a behavioural approach that became popular in various research fields, among which are human geography and location theory (see, among others, Simon [62] ; Pred [53] and [54]; Cox and Golledge [19]). This approach assumes that actors would have limited information, which implies that, unlike the neo-classical theories, the ultimate choice of actors between different alternatives could be based on satisficing behaviour, rather than simply maximisation (based on maximising behaviour). There are three reasons for this: bounded rationality, conflicting goals, and relocation costs (McCann [48]). First, when considering location issues (either or not related to multifunctional land use), it would appear that the ability of the actor to be rational is very much bounded by limited 
information about, for example, behaviour and goals of actors in the other layers in Figure 2 , the quality and availability of real estate, and local economic environments. In such circumstances, it appears to be beyond the ability of the firm to base its decisions on straightforward expected profit maximising behaviour. Second, because of conflicting goals as a result of separation of ownership from decision making, objectives are frequently pursued which are different from simply profit maximisation. Corporate decisions, for example, are the result of the many individual decisions made by a complex hierarchy of people, each with particular business objectives, many of which are different from profit maximisation. Third, the size of relocation costs may hamper an actor's possibility to move in response to small variations in the benefits obtained from its current location.

Clearly, the behaviour of the three types of beneficiaries may be constrained or encouraged by (local) public policy actions (e.g., taxation, zoning) because of the externalities involved with multifunctional land use design.

\section{A Typology of Actors}

The present section will briefly characterise the way in which different types of economic beneficiaries pursue their goals, and identify possible variables that influence their profitability or utility. Local governments are not direct beneficiaries as such, but impact of course on the behaviour of these actors.

\subsection{Investors}

The main objective of property developers and institutional investors is to make a profit on their activities. The way in which they realise profits differs. Property developers, on the one hand, make profits by developing buildings and selling or renting them to either the final users or institutional investors. Institutional investors, on the other hand, use the real estate market (as part of their portfolio) to get returns on investment. Generally, they try to combine the highest return with the lowest level of risk (Vos [67]). On the (Dutch) commercial property market, risks are perceived to be low (van der Krabben and Lambooy [42]), and the returns on investment in the long run are expected to be higher than those on government bonds, which provide a low risk-free return (van der Krabben [40]). The level of risk that the investor is prepared to accept for the level of return required for a particular type of investment determines the choice for investment (Eccles et al. [23]).

The need to diversify the portfolio structure has increasingly led investors to target opportunities internationally, particular city locations (Berry and McGreal [9]). This might suggest an increasing interest in multifunctional land use projects, since these are to be found in (international) city centres and provide opportunities for diversification of the portfolio structure. Such opportunities can also be found within multifunctional land use projects. For example, fluctuations in the real estate markets of the different land use functions (offices, houses, (retail) facilities) could be absorbed by the other land use functions if the real estate is owned by one owner. Furthermore, when the diversity of land use functions at the site increases and a property developer develops property for different land use functions, he might be able to partly internalise the benefits that may arise as a result of the combination of different land use functions. This implies that diversity in land use 
functions is one of the variables that could influence the profitability of investors in multifunctionally-designed areas. Another important determinant is the level of property rent they can ask to tenants : the higher the level of property rent, the higher their profits will be. We expect rents to be influenced by the degree of multifunctionality of the area considered, since a positive valuation of a multifunctional design by tenants will be expressed in their willingness to pay higher rents. It is thus important for investors to have knowledge about preferences of other types of actors, i.e. those elements of multifunctional land use that influence their profitability or utility, and with that, their willingness to pay. The importance of such knowledge is also illustrated by mainstream economic theories, which suggest that the outcomes of economic forces may depend heavily on local market structures (Ball et al. [3]).

This overview illustrates that benefits of a multifunctional design that influence the profitability of investors are generally expressed by the possibility to spread risk as a result of diversity in land use functions and the level of property rent they can ask for property in a multifunctionally-designed area.

\subsection{Production organisations}

Business organisations (firms, retailers, etc.) consider prices per square metre of office or retail space in the light of value added. In order to maximise profits, they prefer low rents, but they also take external factors into consideration that do not directly influence their core activities. Examples of variables that influence the profitability of organisations in multifunctionally-designed areas are, apart from profits resulting from the organisations' core activities, benefits from localisation and/or urbanisation advantages, and attractiveness for employees and clients. These variables are strongly determined by locational characteristics, which are often distinguished into four categories: location and accessibility, labour market, market characteristics, and other characteristics. Many examples of locational characteristics for each category can be found in literature on location choice (e.g. Pellenbarg [51] ; Korteweg and Lie [39] ; Bruinsma and Rietveld [10]). A multifunctional design of an area will bring changes in locational characteristics, such as an improved accessibility, the addition of other land use functions to the area, a better image, etc. The valuation of such changes in locational characteristics by organisations, as well as the point of indifference between these characteristics, is clearly important. Although the values may become uncertain when organisations have imperfect information as in the behavioural approach, there is no reason to assume a systematic bias in the valuation of different characteristics under the assumption of maximising behaviour.

Localisation and/or urbanisation advantages are important determinants of the profitability of organisations, since clustering of companies provides labour market economies. Search costs and moving costs will become lower, so that firms are able to increase or decrease their workforce more easily (Rosenthal and Strange [60]). This is not a benefit that is specific for multifunctional land use, but is a result of one of its likely consequences : namely, intensification. Furthermore, firms in a cluster can exploit scale economies by sharing the providers of specialised services, which is especially relevant when transport costs are high. At this location, they can share specialised services, reduce transportation 
costs, and benefit from a joint image, advantages that are apparently expected to counterbalance the higher rents they have to pay for the location.

The public perception (image) of a location is another important determinant of the profitability of organisations in multifunctionally-designed areas. Together with accessibility of the location, it influences the company's attractiveness for employees and clients (Korteweg and Lie [39]). Image is considered important by the work and business sector and for retail and private services; they might consider renting floor space at multifunctional sites with a prestigious design in order to improve their image and thus become more attractive for clients and employees. Organisations looking for office or retail space compare the higher rents of these locations with the costs of alternative strategies of searching for customers (Webster and Lai [70]). The higher they expect the benefits of a multifunctional design to be, the higher the rents that they are willing to pay. Accessibility of the site also plays an important role in considerations about the level of property rent that companies are willing to pay, and thus in determining their profitability. Examples of variables are the number of parking places, amount of congestion, and frequency of public transport services (which might be enhanced because of an increase in economics of density as a result of a multifunctional design of the area) (see also NSS [49] ; Bruinsma et al. [11] ; van Dijk and Pellenbarg [21]).

The analysis above shows that changes in locational characteristics as a result of a multifunctional design of the area are important attributes of the profitability of organisations located in such areas.

\subsection{Individual users}

The group of individual users consists of people who make use of the different land uses offered at a multifunctionally-designed site (such as shops, sporting facilities, catering facilities, housing, transport services, etc.). Within this group, employees, residents, travellers and shoppers can be distinguished. Generally, employees and residents constitute an important share of users of different services offered at the site.

Spatial planning (e.g. a multifunctional design) influences the daily life of individual users in many dimensions since it defines places to live, to work, to recreate, etc. Such changes may have major consequences for their patterns of everyday life (Healey [32]). Choices that individuals make are influenced by habit, inertia, experience, advertising, environmental constraints, accumulated opinion, household and family constraints, etc. (Loeviere [46]) and are restricted by the resources (e.g. money, time) available to them (van der Knaap [38]).

Benefits that individual users derive from their choices are expressed in utility. Utility is derived from the characteristics which goods (in our case, a multifunctional design) possess, rather than the goods per se (Lancaster [43] and [44]). We therefore assume that individuals act as if they maximise utility (i.e. benefits) based on their perceptions of characteristics of a multifunctional design. In the light of assessing the marginal valuation of specific attributes of multifunctional land use projects, we are interested in those attributes that influence the utility of individual users.

For individual users, especially the variety of services offered at a multifunctionallydesigned site, as well as housing opportunities are important. The better the variety of 
services offered meets their preferences, the higher their utility level will be. This will result in a higher willingness to pay (WTP) for the use of the facilities. Housing opportunities are assessed in terms of living satisfaction, which is defined by geographical location, access to work and shopping, etc. Residents thus buy a set of attributes (of which multifunctionality is one), and not merely a physical living unit (Jaffe and Sirmans [36]). The better these attributes meet their preferences, the higher their utility level will be, and, with that, their WTP for the property.

Other important aspects that influence the utility level of individual users are accessibility of the site, but also the outside options they have. When, ceteris paribus, the home situation among individual users differs from a multifunctionally-designed site in terms of, for example, the presence of a railway station and different types of shops, the extra utility they derive from the use of a multifunctionally-designed site, and thus their WTP, may differ strongly over users.

\section{Concluding Remarks}

In densely populated areas, multifunctional land use is an interesting urban planning concept, as it seeks to combine the economic efficiency arguments on high land rents with the environmental quality needs in cities. The number of actors involved with multifunctional urban land use is normally considerable and this may complicate effective strategic decisionmaking. In the present paper we have adopted a typological approach by distinguishing major classes of beneficiaries (or stakeholders), so that we could systematically map out their interests.

Each group of these stakeholders will try to maximise the total benefits they derive from multifunctional land use projects. Under this assumption, the most important determinant for the benefits that investors derive from a multifunctional design is the extra property rent they can charge to different kinds of users (organisations and individual users) (i.e. rent minus costs). Organisations make a trade-off between the relatively higher real estate prices or rents they will have to pay at the multifunctional site and the value added they expect from being located in such an area. Individual users, on the other hand, measure benefits in terms of utility. Benefits that individual users derive from a multifunctionally-designed location are dependent on the extent to which their preferences are met and the outside options they have. To get an idea of the size of the total expected benefits for individual users of a multifunctionally-designed area, one needs to analyse each type of actor in this group (employees, residents, travellers and shoppers). Individual users express the benefits they derive from living in or using the facilities in a multifunctionally-designed area by the higher prices they are willing to pay for property, products, and services they buy at the multifunctionally-designed site, or by their willingness to accept lower wages. In conclusion, multifunctional land use prompts interesting research questions of a complex nature. An actor-oriented approach offers clearly a fruitful framework for further empirical work on the economic benefits for various classes of stakeholders. Comparative case study research may be a promising methodological vehicle in this context. 


\section{References}

[1] Alonso, W., Location and Land Use, Harvard University Press, Cambridge, MA, 1964.

[2] American Planning Association, Principles of Smart Growth, American Planning Association Press, Chicago, IL, 1999.

[ 3 ] Ball, M., Lizieri, C. and McGregor, B., The Economics of Commercial Property Markets, Routledge, London, 1998.

[ 4 ] Banister, D., Energy Use, "Transport and Settlement Patterns", In : M. Breheny (ed.), Sustainable Development and Urban Form, Pion, London, 1992, pp. 160-181.

[5] Banister, D., "Viewpoint: Reducing the Need to Travel through Planning", Town Planning Review, Vol. 65, No. 4, 1994, pp. 349-354.

[6] Banister, D., Transport and Urban Development, E \& FN Spon, London, 1995.

[ 7 ] Banister, D., "Planning More to Travel Less: Land Use and Transport", Town Planning Review, Vol. 70, No. 3, 1999, pp. 313-338.

[8] Banister, D. and Berechman, J., Transport Investment and Economic Development, University College London Press, London, 2000.

[ 9 ] Berry, J. and McGreal, S., European Cities, Planning Systems and Property Markets, E \& FN Spon, London, 1995.

[10] Bruinsma, F.R. and Rietveld, P., "A Stated Preference Approach to Measure the Relative Importance of Location Factors; a Case Study for the Eastern part of the Netherlands", International Journal of Development Planning Literature, Vol. 12, Nos. 1 \& 2, 1995, pp. 125-140.

[11] Bruinsma, F.R., Rienstra, S.A. and Rietveld, P., "Economic Impacts of the Construction of a Transport Corridor; A Multi-Level and Multi-Approach Case Study for the Construction of the A1 Highway in the Netherlands", Regional Studies, Vol. 31, No. 4, 1997, pp. 391-402.

[12] Capello, R. and Nijkamp, P., "In Search of Sustainable Human Settlements ; Prefatory Remarks", Ecological Economics, Vol. 40, No. 2, 2002, pp. 151-155.

[13] Carsjens, G.J. and van der Knaap, W., "Strategic Land-Use Allocation: Dealing with Spatial Relationships and Fragmentation of Agriculture", Landscape and Urban Planning, Vol. 58, No. 204, 2002, pp. 171-179.

[14] Carson, R., Silent Spring, Houghton Mifflin Co., Boston, 1962.

[15] Centraal Planbureau (CPB), De Grondmarkt; Een Gebrekkige Markt en een Onvolmaakte Overheid, Sdu Uitgevers, Den Haag, 1999.

[16] Cervero, R.B., America's Suburban Centers : The Land Use-Transportation Link, Unwin-Hyman, Boston, 1989.

[17] Congress for the New Urbanism, Charter of the New Urbanism, McGraw-Hill, New York, 2000.

[18] Coupland, A., "An Introduction to Mixed Use Development”, In: Coupland, A. (ed.), Reclaiming the City ; Mixed Use Development, E \& FN Spon, London, 1997.

[19] Cox, K.R. and Golledge, R.G., Behavioural Problems in Geography Revisited, Methuen, New York, 1981.

[20] Cullingworth, J.B., "Alternate Planning Systems; Is there Anything to Learn from Abroad?", Journal of the American Planning Association, Vol. 60, No. 2, 1994, pp. 162-172.

[21] Dijk, J. van and Pellenbarg, P., "Firm Relocation Decisions in the Netherlands. An Ordered Logit Approach”, Papers in Regional Science, Vol. 79, No. 2, 2000, pp. 191-219.

[22] Dowall, D.E., Theories of Urban Form and Land Use: A Review, Working Paper 295, Institute of Urban \& Regional Development, University of California, Berkeley, 1978.

[23] Eccles, T., Sayce, S. and Smith, J., Property and Construction Economics, International Thomson Business Press, London, 1999.

[24] Fujita, M., Urban Economic Theory: Land Use and City Size, Cambridge University Press, Cambridge, 1989. 
[25] Furubotn, E.G. and Richter, R., Institutions and Economic Theory: The Contribution of the New Institutional Economics, The University of Michigan Press, Ann Arbor, 1997.

[26] Glaeser, E.L., Kolko, J. and Saiz, A., "Consumer City”, Journal of Economic Geography, Vol. 1, No. 1, 2001, pp. 27-50.

[27] Grant, J., "Mixed Use in Theory and Practice: Canadian Experience with Implementing a Planning Principle", Journal of the American Planning Association, Vol. 68, No. 1, 2002, pp. 71-84.

[28] Griffin, P.F., Singh, A., Rodgers, W., White and Chatham, R.L., Culture, Resource, and Economic Activity; An Introduction to Economic Geography, Allyn and Bacon, Boston, MA, 1976.

[29] Hall, P., Cities in Civilisation, Pantheon, New York, 1998.

[30] Harts, J.J., Maat, C., and Zeijlmans van Emmichoven, D., Meervoudig Stedelijk Ruimtegebruik; Methode en Analyse, Stedelijke en Regionale Verkenningen 20, Delft University Press, Delft, 1999.

[31] Harvey, J., Urban Land Economics, MacMillan Press Ltd., London, 2000.

[32] Healey, P., Collaborative Planning : Shaping Places in Fragmented Societies, MacMillan Press Ltd., London, 1997.

[33] Isard, W., Location and Space-Economy; A General Theory Relating to Industrial Location, Market Areas, Land Use, Trade, and Urban Structure, MIT Press, Cambridge, MA, 1968.

[34] Jacobs, J., The Death and Life of Great American Cities, Random House, New York, 1961.

[35] Jaffe, A.B., Trajtenberg, M. and Henderson, R., "Geographic Localisation of Knowledge Spillovers as Evidenced by Patent Citations”, Quarterly Journal of Economics, Vol. 108, No. 3, 1993, pp. 577598.

[36] Jaffe, A.J. and Sirmans, C.F., Fundamentals of Real Estate Investment, Prentice Hall, Englewood Cliffs, N.J, 1995.

[37] Johansson, P., An Introduction to Modern Welfare Economics, Cambridge University Press, Cambridge, 1991.

[38] Knaap, G.A. van der, Stedelijke Bewegingsruimte; Over Ontwikkelingen in Stad en Land, Wetenschappelijke Raad voor het Regeringsbeleid, Sdu Uitgevers, Den Haag, 2002.

[39] Korteweg, P. and Lie, R., "Prime Office Locations in The Netherlands", Tijdschrift voor Economische en Sociale Geografie, Vol. 83, No. 4, 1992, pp. 250-262.

[40] Krabben, E. van der, Het Functioneren van Stedelijke Onroerend-Goed-Markten in Nederland; Een Theoretisch Kader, Research Memorandum FEW 514, Katholieke Universiteit Brabant, Tilburg, 1991.

[41] Krabben, E. van der and Lambooy, J.G., "A Theoretical Framework for the Functioning of the Dutch Property Market”, Urban Studies, Vol. 30, No. 8, 1993, pp. 1381-1397.

[42] Krabben, E. van der and Lambooy, J.G., An Institutional Economic Approach to Land and Property Markets ; Urban Dynamics and Institutional Change, Research Memorandum FEW 636, Katholieke Universiteit Brabant, Tilburg, 1994.

[43] Lancaster, K., “A New Approach to Consumer Theory”, Journal of Political Economy, Vol. 74, 1966, pp. $132-157$.

[44] Lancaster, K., Consumer Demand ; a New Approach, Columbia University Press, New York, 1971.

[45] Lambooy, J.G., The Urban Spatial Structure and Agglomeration Economies : Relations with Real Estate, Discussion Paper 1996-141/5, Tinbergen Institute, Amsterdam, 1996.

[46] Louviere, J.J., Hensher, D.A. and Swait, J., Stated Choice Methods ; Analysis and Application, Cambridge University Press, Cambridge, 2003.

[47] Maat, K., "Effects of the Dutch Compact City Policy on Travel Behaviour", In : Feitelson, E. and Verhoef, E.T. (eds), Transport and Environment : In Search of Sustainable Solutions, Edward Elgar, Cheltenham, 2002, pp. 208-230.

[48] McCann, P., Urban and Regional Economics, Oxford University Press Inc., New York, 2001.

[49] NSS, Eisen aan de Bedrijfsomgeving in de Randstad, NSS beleidsonderzoek en beleidsadvies, Den Haag, 1991. 
[50] O'Sullivan, A., Urban Economics, $5^{\text {th }}$ edition, McGraw-Hill/Irwin, Boston, 2003.

[51] Pellenbarg, P.H., Bedrijfsrelokatie en Ruimtelijke Kognitie; Onderzoekingen naar Bedrijfsverplaatsingsprocessen en de Subjectieve Waardering van Vestigingsplaatsen door Ondernemers in Nederland, Sociaal-Geografische Reeks, No.33, Geografisch Instituut, Rijksuniversiteit Groningen, Groningen, 1985.

[52] Pellenbarg, P.H., van Wissen, L.J.G. and van Dijk, J., Firm Relocation: State of the Art and Research Prospects, SOM Research Report 02D31, University of Groningen, Groningen, 2002.

[53] Pred, A.R., Behaviour and Location: Foundations for a Geographic and Dynamic Location Theory: Part 1, University of Lund, Lund Studies in Geography B, No. 27, Lund, 1967.

[54] Pred, A.R., Behaviour and Location: Foundations for a Geographic and Dynamic Location Theory: Part 2, University of Lund, Lund Studies in Geography B, No. 28, Lund, 1969.

[55] Priemus, H, Rodenburg, C.A. and Nijkamp, P., "Multifunctional Land Use: A New Phenomenon? A New Planning Challenge?”, Built Environment, Vol. 30, No. 4, 2004, pp. 269-273.

[56] Ricardo, D., On the Principles of Political Economy and Taxation, John Murray, London, 1821.

[57] Rietveld, P., Infrastructure and Regional Development: A Survey of Multiregional Economic Models, Annals of Regional Science, Vol.23, No.4, 1989, pp. 255-274.

[58] Rietveld, P., "Spatial Economic Impacts of Transport Infrastructure Supply", Transportation Research A, Vol. 28, No. 4, 1994, pp. 329-341.

[59] Rodenburg, C.A., Vreeker, R. and Nijkamp, P., "Multifunctional Land Use ; An Economic Perspective”, In: Nijkamp, P., Rodenburg, C.A. and Vreeker, R. (eds), The Economics of Multifunctional Land Use, Shaker Publishing B.V., Maastricht, 2003, pp. 3-15.

[60] Rosenthal, S.S. and Strange, W.C., "Evidence on the Nature and Sources of Agglomeration Economies”, In: Henderson, J.V. and Thisse, J-F. (eds), Handbook of Urban and Regional Economics, Vol. 4, 2004, Elsevier, Amsterdam.

[61] Shefer, D., "Economic Aspects of Multifunctional Land Use and Urban Rejuvenation", In: Nijkamp, P., Rodenburg, C.A. and Vreeker, R. (eds), The Economics of Multifunctional Land Use, Shaker Publishing B.V., Maastricht, 2003, pp. 123-124.

[62] Simon, H.A., “A Behavioural Model of Rational Choice”, Quarterly Journal of Economics, Vol. 69, No. 1, 1955, pp. 99-118.

[63] Stiglitz, J.E., Economics of the Public Sector, $2^{\text {nd }}$ ed., W.W. Norton \& Company, New York, 1988.

[64] Stiglitz, J.E. and Driffill, J., Economics, W.W. Norton \& Company, New York, 2000.

[65] Thunen, J.H. von, Der Isolierte Staat in Beziehung auf Landwirtschaft und Nationalökonomie, Hamburg, Rostock, Germany, 1825.

[66] Varian, H.R., Microeconomic Analysis, $3^{\text {rd }}$ ed., W.W. Norton \& Company, New York, 1992.

[67] Vos, G., "International Real Estate Portfolios". In : Berry, J., McGreal, S. and Deddis, W., Urban Regeneration, Property Investment and Development, E \& FN Spon, London, 1993, pp. 16-31.

[68] Vreeker, R., de Groot, H.L.F., and Verhoef, E.T., "Urban Multifunctional Land Use ; Theoretical and Empirical Insights on Economies of Scale, Scope and Diversity", Built Environment, Vol. 30, No. 4, 2004, pp. 289-307.

[69] Walker, H., "Mixed Use Development as an Agent of Sustainability", In: Coupland, A. (ed.), Reclaiming the City ; Mixed Use Development, Spon, London, 1997.

[70] Webster, C. and Wai-Chung Lai, L., Property Rights, Planning and Markets : Managing Spontaneous Cities, Edward Elgar Publishing, Cheltenham, 2003.

[71] Williamson, O.E, Markets and Hierarchies ; Analysis of Anti-Trust Implications, Free Press, New York, 1975. 